\title{
HALREV
}

Hasanuddin Law Review

\section{Undang-Undang sebagai Sarana Pembaharuan bagi Masyarakat (Telaah Sosiologis Keberlakuan Undang-Undang Nomor 6 Tahun 2014 tentang Desa)}

\author{
Law as a Medium of Reformation for Society (Sociological Research of the \\ Prevailing of the Law No. 6 Year 2014 concerning the Village)
}

\section{Gusti Bagus Suryawan}

Fakultas Hukum, Universitas Warmadewa.

Jln. Terompong No. 24, Tanjung Bungkak, Denpasar, Bali.

Tel./Fax: 2355073 E-mail: igbsuryawan_gusti@yahoo.com

Submitted: Feb 4, 2015; Reviewed: Mar 13, 2015; Accepted: Mar 22, 2015

\begin{abstract}
Law No. 6 Year 2014 about the Village mentioned that, every village in all Indonesia territories gets fund allocation from the National Budget. This fund is used for the development which is village based. Total mentioned allocated fund is up to $10 \%$ from the balanced fund received by the Regency/City in National Budget after being reduced by the Special Allocation Fund. Theoretically this research has purpose to find out the role of the Village Law as a medium for reformation of the society. Mochtar Kusumaatmadja saw the changing of the attitude to legislation which shows the balance between the will to perform law reformation through legislation and the awareness to also give attention to the values and facts that is life in the society. The Village Law becomes the foundation and part of the reformation of mind setting, action setting of the village people. The Law about village is properly also as the instrument to develop the new village living which is autonomous, democratic and prosperous.
\end{abstract}

Keywords: Balancing Fund, Local Government; Regional Autonomy, Village

Abstrak: Undang-Undang Nomor 6 Tahun 2014 tentang Desa menegaskan, setiap desa di seluruh Indonesia mendapat alokasi dana dari Anggaran Pendapatan dan Belanja Negara. Dana tersebut digunakan untuk pembangunan yang berbasis desa. Total dana yang dialokasikan tersebut mencapai $10 \%$ dari dana perimbangan yang diterima Kabupaten/ Kota dalam Anggaran Pendapatan dan Belanja Daerah setelah dikurangi Dana Alokasi Khusus. Secara teoritis penelitian ini bertujuan untuk mengetahui peranan UndangUndang Desa sebagai sarana pembaharuan masyarakat. Mochtar Kusumaatmadja melihat perubahan sikap terhadap perundang-undangan yang menampakkan keseimbangan antara keinginan untuk mengadakan pembaharuan hukum melalui perundang-undangan dan kesadaran diperhatikannya pula nilai-nilai dan kenyataan yang hidup dalam masyarakat. Undang-Undang Desa menjadi landasan dan bagian dari pembaharuan pola pikir, pola tindak masyarakat desa. Undang-Undang Desa seyogianya juga merupakan instrumen untuk membangun kehidupan baru desa yang mandiri, demokratis, dan sejahtera.

Kata Kunci: Dana Perimbangan; Desa; Otonomi Daerah; Pemerintah Daerah 


\section{PENDAHULUAN}

Eksistensi desa pada hakikatnya merupakan bentuk pemerintahan yang riil, demokratis, otonom dengan tradisi, adat-istiadat dan hukumnya sendiri yang mengakar sangat kuat, serta relatif mandiri dari "campur tangan" entitas kekuasaan dari luar. Tetapi ironisnya, dalam berbagai kebijakan lebih ditempatkan sebagai “objek kekuasaan” daripada "subjek kekuasaan". Peraturan perundang-undangan yang mengatur desa selama ini menunjukkan inkonsistensi dan ketidaksesuaian antara UUD NRI 1945 dengan undang-undang organiknya, baik pada tataran asas, konsep maupun hirarkinya.

Hal ini dapat dilihat pada kerangka pemikiran konstitusionalisme, yaitu pemerintahan berdasarkan konstitusi dimana tercakup konsepsi bahwa secara struktural, daya jangkau kekuasaan wewenang organisasi negara dalam mengatur pemerintahan hanya sampai pada tingkat kecamatan ${ }^{1}$. Artinya, secara akademis semakin mempertegas bahwa organ yang berada di bawah struktur organisasi kecamatan dapat dianggap sebagai organ masyarakat dan masyarakat desa dapat disebut sebagai self governing communities yang sifatnya otonom. Semangat konsep self governing communities dan local authority, secara konstitusional telah dikukuhkan dalam Perubahan UUD NRI 1945, Pasal 18 B ayat (1) dikenal dengan "otonomi khusus" dan ayat (2) pengakuan dan penghormatan

1 I Dewa Gede Atmadja. (2008). Awig-Awig Desa Adat Bali: Suatu Analisis Hukum Tata Negara, Dalam Dinamika Perkembangan Hukum Tata Negara dan Hukum Lingkungan, Edisi Khusus Kumpulan Tulisan dalam rangka Purnabakti Prof. Dr. Siti Sundari Rangkuti, S.K. Surabaya: Airlangga University Press, hlm. 265. terhadap "masyarakat hukum adat", seperti desa di Jawa, Bali, dan Nagari di Minangkabau.

Landasan pemikiran pengaturan desa yang mengakui dan menghargai keanekaragaman, partisipasi, otonomi asli, demokratisasi dan pemberdayaan masyarakat dalam UUD NRI 1945 sebelum dan sesudah perubahan, tetapi dalam beberapa undangundang yang mengatur pemerintahan desa justru muncul kehendak untuk menyamaratakan bahkan cenderung mematikan demokrasi dan membuat ketergantungan desa pada Pemerintah Kabupaten atau Kota, Pemerintah Provinsi atau Pemerintah Pusat.

Implikasi berubah-ubahnya politik hukum pemerintahan desa, berakibat pada hancurnya kehidupan politik, hukum, ekonomi dan sosial budaya di desa. Secara empirik dalam politik nampak hilangnya basis sosial (kepemimpinan, pranata sosial, lembaga-lembaga adat).

Dalam bidang hukum, konsep penguasaan negara atas bumi, air dan kekayaan alam yang terkandung di dalamnya, dalam implementasinya telah menjadi alat untuk menghilangkan kedaulatan masyarakat adat atas sumber daya alamnya. Bidang ekonomi, nampak dari sumberdaya alam masyarakat adat telah menjadi objek pemerintah dan pemodal swasta untuk mendirikan dan mengoperasikan proyekproyek besar.

Di bidang sosial-budaya, yaitu dihilangkannya berbagai pengetahuan dan kearifan lokal milik masyarakat adat, seperti: sistem bera pada masyarakat Dani di Lembah Bilem, sistem sasi pada masyarakat Negeri Haruku, sistem perladangan berotasi 
pada masyarakat Dayak. ${ }^{2}$

Secara global, isu mengenai otonomi daerah banyak mengemuka di negara-negara sedang berkembang, utamanya menyangkut persoalan penyebaran kekuasaan. Otonomi merupakan penerapan konsep teori areal division of power yang membagi kekuasaan secara vertikal, menyebabkan adanya kewenangan penyelenggaraan pemerintahan oleh pemerintahan pusat dan pemerintahan daerah. $^{3}$

Cita hukum dalam Pasal 18B UUD NRI 1945 adalah: (1) Pengakuan dan penghormatan terhadap satuan-satuan pemerintahan daerah yang bersifat khusus atau bersifat istimewa; (2) Pengakuan dan penghormatan terhadap satuan-satuan pemerintahan daerah yang bersifat khusus atau bersifat istimewa diatur dengan undang-undang; dan (3) negara mengakui dan menghormati kesatuan-kesatuan masyarakat hukum adat beserta hak-hak tradisionalnya dengan sebuah persyaratan, yaitu sepanjang masih hidup dan sesuai dengan perkembangan masyarakat dan prinsip Negara Kesatuan Repubhk Indonesia yang diatur dalam undangundang.

Pada tataran undang-undang, secara kronologis tampak sebagai berikut:

a) UU No. 1 Tahun 1945 tentang Otonomi Daerah merupakan peraturan

2 R. Yando Zakaria dan Abih Tandeh. (2000). Masyarakat Desa di Bawah Rejim Orde Baru. Jakarta: Lembaga Studi dan Advokasi Masyarakat (ELSAM), hlm. 1. Lihat juga dalam Sadu Wasistiono. (2006). Prospek Pengembangan Desa. Bandung: Lembaga Kajian Manajemen Pemerintahan Daerah, Fokus Media, hlm. 18.

3 Wasisto Raharjo Jati, Inkonsistensi Paradigma Otonomi Daerah di Indonesia, Jurnal Konstitusi, 9(4) Desember 2012: 747. desentralisasi pertama dan menempatkan desa sebagai letak otonomi terbawah serta sebagai kesatuan masyarakat yang berhak mengatur rumah tangga pemerintahannya sendiri. ${ }^{4}$

b) UU No. 22 Tahun 1948 tentang Pemerintahan Daerah, memberikan pengakuan dan perlindungan terhadap eksistensi desa sebagai kesatuan masyarakat yang memUiki asal usul dan berhak mengatur dan mengurus pemerintahannya sendiri dan meng-arahkan desa, negari, marga dan sebagainya menjadi Daerah Otonom Tingkat III ${ }^{5}$;

c) UU No. 1 Tahun 1957 tentang Pokokpokok Pemerintahan Daerah, secara filsufis membagi daerah otonom menjadi dua jenis, yaitu daerah otonom biasa dan daerah swapraja dan mengusung filosofi keberagaman;

d) UU No. 19 Tahun 1965 tentang Desa Praja, mengusung semangat penyeragaman (Desapraja) dan pembentukan daerah tingkat III;

e) UU No. 5 Tahun 1979 tentang Pemerintahan Desa, menyeragamkan nama, bentuk, susunan dan kedudukan pemerintahan desa;

f) UU No. 22 Tahun 1999 tentang Pemerintahan Daerah, memberikan pengakuan terhadap keragaman dan keunikan desa sebagai manifestasi makna “istimewa” Pasal 18 UUD NRI 1945;

4 Bagir Manan. (1990). Hubungan antara Pusat dan Daerah Berdasarkan Asas Desentralisasi Menurut UUD 1945 disertasi doktor dalam Hukum Tata Negara. Bandung: Pascasarjana Universitas Padjadjaran, hlm. 183.

Loc. Cit. 
g) UU No. 32 Tahun 2004 tentang Pemerintahan Daerah, melokalisir desa sebagai subyek hukum yang mengelola kepentingan masyarakat setempat, bukan urusan atau kewenangan pemerintahan, seperti halnya daerah. Negara hanya "mengakui" keberadaan desa, tetapi tidak "membagi" kekuasaan pemerintahan kepada desa. Desa hanya diakui sebagai kesatuan masyarakat hukum berdasarkan asal-usul dan adatistiadat, bukan disiapkan sebagai entitas otonom (local self government).

Setelah beberapa kali tertunda karena adanya perdebatan keras di DPR RI maupun dengan pemerintah, akhirnya Rancangan Undang-Undang Desa disahkan menjadi Undang-Undang dalam rapat paripurna di Senayan, tanggal 18 Desember 2013. ${ }^{6}$ Pengesahan Undang-Undang ini monumental, karena mengatur beberapa hal baru yang ditujukan untuk meningkatkan pembangunan nasional, mulai dari desa. Berdasarkan Undang-Undang Nomor 6 Tahun 2014 tentang Desa tersebut, setiap desa di seluruh Indonesia akan mendapat alokasi dana dari Anggaran Pendapatan dan Belanja Negara yang bersumber dari belanja pusat. Dana tersebut akan digunakan untuk pembangunan yang berbasis desa.

Total dana yang dialokasikan tersebut mencapai $10 \%$ dari dana perimbangan yang diterima Kabupaten/Kota dalam APBD setelah dikurangi Dana Alokasi Khusus. Wakil Ketua Pansus RUU Desa Budiman Sujatmiko mengatakan, dana sekitar Rp104,6 triliun bila dibagi untuk sekitar 72.000 desa

\footnotetext{
6 Source: Nias Online, diunduh pada tanggal 21
} Juni 2014. maka setiap desa mendapatkan dana sekitar Rp 1,4 miliar per tahun. "Namun, besaran dana yang diterima akan disesuaikan dengan geografis, jumlah penduduk dan jumlah penduduk miskin di desa itu." ${ }^{\prime 7}$ Terlepas jika ada nuansa politis di balik terbentuknya UU Desa ini, menjadi satu momentum baik untuk dimulainya pembangunan mulai dari desa di seluruh Indonesia dan sekaligus menjadi objek kajian dalam tulisan ini.

\section{METODE}

Penelitian ini menggunakan metode pendekatan hukum normatif, dengan mengidentifikasi materi muatan dalam UndangUndang Nomor 6 Tahun 2014 tentang Desa, yang diasumsikan akan dapat menjadi sarana pembaharuan masyarakat desa. Pendekatan yang digunakan, adalah: (1) Pendekatan undang-undang (statute approach); (2) Pendekatan konseptual (conceptual approach); (3) Pendekatan sejarah (historical approach); (4) Pendekatan Perbandingan (comparative approach). ${ }^{8}$

Prosedur pengumpulan bahan hukum dengan menelusuri undang-undang yang mengatur tentang desa. Adapun bahan hukum yang diperoleh melalui studi kepustakaan dan peraturan perundang-undangan dianalisis secara kualitatif. Dalam kerangka memahami makna dari teks hukum dengan menggunakan metode hermeunitika yang meliputi metode interpretasi dan metode

\footnotetext{
Ibid.

8 Hadin Muhjad dan Ninuk Nuswardani. (2012). Penelitian Hukum Indonesia Kontemporer, Yogyakarta: Genta Publishing, hlm. 46.
} 
konstruksi. ${ }^{9}$ Pengolahan bahan hukum dilakukan dengan metode interpretasi meliputi interpretasi gramatikal dan interpretasi teleologis.

Secara teoretis, penelitian ini bertujuan untuk mengetahui peranan aktif hukum (Undang-Undang tentang Desa) sebagai sarana pembaharuan sosial masyarakat. Dengan mencermati proses pembentukan dan juga materi muatan undang-undang tentang desa ini, penulis akan melakukan kajian perspektif sosiologis yakni melihat penerapan konsep hukum, yaitu bahwa hukum merupakan sarana pembaharuan masyarakat sebagaimana diintrodusir oleh Mochtar Kusumaatmadja ${ }^{10}$ sebagai modifikasi dari ide awal yang dikemukakan oleh Roscoe Pound.

\section{ANALISIS DAN PEMBAHASAN}

\section{Hukum sebagai Sarana Pembaharuan Masyarakat}

Untuk pembentukan peraturan perundangundangan, aspek kepentingan merupakan suatu bahan pertimbangan yang amat penting.

Dalam hal ini Roscoe Pound menyatakan bahwa hukum harus mengharmoniskan kepentingan umum dan kepentingan individual melalui cita-cita keadilan yang hidup dalam masyarakat. ${ }^{11}$ Dalam konteks ini, hukum berperan aktif dan sering disebut

Loc. Cit.

10 Mochtar Kusumaatmadja. (1976). Hukum, Masyarakat dan Pembinaan Hukum Nasional, Suatu Uraian tentang Landasan Pikiran, Pola dan Mekanisme Pembaharuan Hukum di Indonesia. LPHK Fakultas Hukum Universitas Padjajaran. Bandung: Penerbit Binatjipta, hlm. 1.

11 Achmad Ruslan. (2013). Teori dan Panduan Praktik Pembentukan Peraturan Perundangundangan di Indonesia. Yogyakarta: Rangkang Education dan Republik Institut, hlm. 97. sebagai fungsi a tool of social engineering. ${ }^{12}$

Historisme menentang suatu legislation sebagai suatu cara untuk membuat dan memperbaharui hukum. Mochtar Kusumaatmadja melihat perubahan sikap terhadap perundang-undangan yang menampakkan keseimbangan antara keinginan untuk mengadakan pembaharuan hokum melalui perundang-undangan dan kesadaran diperhatikannya pula nilai-nilai dan kenyataan yang hidup dalam masyarakat. Pendapat Mochtar ini merujuk pada konsep pemikiran Eugen Ehrlich tentang hukum, bahwa hukum positif yang baik dan efektif adalah hukum yang sesuai dengan living law.

Lebih lanjut, Mochtar Kusumaatmadja $^{13}$ berpendapat jika istilah sarana lebih tepat dibandingkan dengan istilah alat, dalam konsep hukum sebagai sarana pembaharuan masyarakat dengan alasan: (1) lebih menonjolkan peran perundangundangan untuk untuk keadaan di Indonesia. Sedangkan esensi konsep Roscoe Pound di Amerika Serikat ditujukan kepada peran putusan dari Supreme Court. (2) masyarakat Indonesia kurang cocok dengan istilah yang berbau mekanik seperti tool juga karena di Indonesia hukum sebagai sarana pembaharuan dipengaruhi juga oleh pendekatan filsafat budaya dan pendekatan policy.

Ada syarat dan kendala dalam pemakaian hukum sebagai sarana pembaharuan masyarakat ini, antara lain: harus dilakukan berdasarkan kebutuhan mendesak

12 Achmad Ali. (2009). Menguak Teori Hukum (Legal Theory) dan Teori Peradilan (Judicialprudence). Jakarta: Prenada Media Grup, hlm. 93.

13 Mochtar Kusumaatmadja, Op.Cit., hlm. 72 
bangsa, perubahan itu hendaknya dilakukan secara teratur dan tertib, kesulitan menerapkan skala prioritas perundang-undangan sesuai kebutuhan masyarakat, kesulitan menyesuaikan dengan kebutuhan dan kesadaran hukum masyarakat.

Era reformasi merupakan kesempatan bagi para politisi dan penyelenggara negara untuk menyepakati pola dasar hubungan pusat-daerah yang berwatak demokratik dan sekaligus efektif memberikan manfaat bagi bangsa dan negara. Rangkaian relasi politik dan pemerintahan nasional dengan lokal itu tercermin dalam sub ordinasi elit lokal oleh elit nasional, kooptasi pemerintahan daerah oleh pemerintah nasional, ketidakpastian politik dan pemerintahan lokal di bawah dominasi kekuasaan sentralisme partai politik dan semuanya itu menjadikan kepentingan rakyat/daerah menjadi terabaikan. ${ }^{14}$

\section{Otonomi Asli Desa}

Arah politik hukum Orde Reformasi berorientasi pada tiga hal, yaitu: (1) demokratisasi sistem pemerintahan, yakni demokratisasi pada tingkat nasional tidak dapat bertahan lama tanpa ditopang demokratisasi di tingkat daerah, (2) meningkatkan pelayanan publik, yakni desentralisasi diyakini akan mampu memangkas rigiditas birokrasi dan meningkatkan otoritas pemerintah daerah sehingga pelayanan kepada masyarakat akan lebih efisien, (3) kebijakan desentralisasi diharapkan akan dapat meningkatkan kepercayaan masyarakat kepada pemerintah untuk selanjutnya tercipta suatu tatanan pemerintahan

14 Arbi Sanit, Politik Lokal di Bawah Pusaran Pemerintah Negara Kesatuan, Jurnal MIPI Edisi 28, 2013. yang responsif, akuntabel, dan terbuka bagi partisipasi masyarakat dalam proses perumusan kebijakan. ${ }^{15}$

Konsep otonomi tepat dalam pembahasan penyelenggaraan pemerintahan desa. Menurut Wasisto, ${ }^{16}$ konteks pemerintahan dalam pembahasan otonomi daerah perlu ditempatkan pada koridor yang tepat. Hal ini dikarenakan implementasi kebijakan otonomi daerah bersinggungan erat dengan paradigma sistem pemerintahan negara yang dianut. Secara global, isu mengenai otonomi daerah banyak mengemuka, utamanya menyangkut persoalan penyebaran kekuasaan. Otonomi merupakan penerapan konsep teori areal division of power yang membagi kekuasaan negara secara vertikal, sehingga muncul kewenangan penyelenggaraan pemerintahan oleh pemerintah pusat, dan pemerintah daerah. ${ }^{17}$

Otonomi adalah wujud dari asas desentralisasi. Desentralisasi sendiri dimaknai sebagai:

Decentralization as generic term for the dispersal of governmental authority and power away from the national centre to other institutions at other levels of government or level of administration. Decentralization is thereby understood as a territorial concept. Authorities and powers are allocated to regional, provincial or local level. ${ }^{18}$

15 Syarif Hidayat. (2007). Too Much Too Soon, Local Elite's Perpective on and The Puzzle of Contemporary Indonesian Regional Autonomy Policy. Jakarta: Raja Grafindo Persada, hlm. 271.

16 Ibid., hlm. 746.

17 Wasisto Raharjo Jati. (2012). Inkonsistensi Paradigma Otonomi Daerah di Indonesia, Jurnal Konstitusi, 9(4): 1-13.

18 International Institute for Democracy and Electoral Assistance. (2011). A Practical Guide to Constitutional Building: Decentralized Forms of Government, Stromsborg, Sweden, available at: http:www.idea.int. 
Sistem penyelenggaraan pemerintahan negara dan daerah seharusnya didukung oleh asas demokrasi, tetapi sebaliknya di Pakistan saat militer yang berkuasa sebagaimana kutipan berikut:

In other countries of the world this system of administration is being supported by democratic representative, but unfortunately, but in Pakistan this system was strengthened during military governments. ${ }^{19}$

Eksistensi dan peranan desa yang sangat vital dalam kebidupan ketatanegaraan $\mathrm{RI}$, telah disadari sejak the founding fathers dalam menyusun konstitusi RI. Secara tegas Soepomo pernah menyatakan perlunya menggunakan desa sebagai model dalam menyusun sistem pemerintahan RI, karena pemimpin harus bisa bersatu jiwa dengan rakyatnya seperti dalam tradisi pemerintahan desa pada masa itu. Soepomo juga menghendaki diakuinya otonomi desa (zelfbesturende landschappen) dalam sistem ketatanegaraan RI.

Negara Republik Indonesia menghormati kedudukan daerah-daerah istimewa tersebut dan segala peraturan negara yang mengenai daerah-daerah itu akan mengingati hak asal-usul daerah tersebut. Uraian dari Penjelasan tersebut menggambarkan bahwa keinginan untuk membentuk self governing community yang bertumpu pada desa telah terdapat sejak penyusunan naskah asli UUD 1945, dengan menyebutnya sebagai zelfbesturende landschappen.

19 Ali Nawaz Soomro and Amir Ali Chandio. (2013). Challenges to Good Government System of Pakistan, The Journal of African and Asia Local Government Studies, 2(4): 4251, available at: http://www.enterforcalpoint. com.
Jika pemikiran itu diikuti sebenarnya yang diinginkan untuk menjadi karakter dari negara Indonesia adalah negara multikultural. Dalam sistem pemerintahan yang berkedaulatan rakyat, pemerintah daerah (kabupaten/kota) disebut sebagai local self government dan desa disebut sebagai self governing community. Ditinjau dari perspektif historis, desa sebagai komunitas otonom bahkan lebih tua dari kecamatan, kabupaten/ kota, provinsi dan negara. Hal itulah yang menjadi landasan untuk memberikan posisi yang kuat dan otonom kepada desa dalam sistem demokrasi. ${ }^{20}$

Pembahasan hubungan timbal balik antara hukum dan masyarakat sangat penting dan perlu dilakukan. Hukum harus dapat tampil ke depan, menunjukkan arah dan memberi jalan bagi pembaharuan. Adanya pertentangan dua konsepsi pemikiran tentang hukum, antara legisme dengan historisme. Legisme menyamakan hukum dengan undang-undang dan menyangka bahwa segala pembuatan hukum termasuk juga pembaharuan hukum di dalamnya, dapat begitu saja dilakukan dengan undang-undang. ${ }^{21}$

UU Desa menjadi landasan dan bagian dari pembaharuan pola pikir, pola tindak masyarakat desa. Undang-Undang Desa seyogianya juga merupakan instrumen untuk membangun kehidupan baru desa yang mandiri, demokratis dan sejahtera. ${ }^{22}$

20 Dikutip pada laman website: $w w w$. forumdesa. org/mudik/mudik/opim.php, [Diakses pada 14 Januari 2015].

21 Mochtar Kusumaatmadja, Op.Cit., hlm. 3

22 Didik Sukriono. (2011). "Politik Hukum Pemerintahan Desa Perspektif Filosofis, Yuridis dan Sosiologis". Jurnal Kertha Wicaksana, 17(2): 176 . 
Kemandirian yang dimaksud adalah bukan kesendirian desa dalam menghidupi dirinya sendiri, tetapi terkait dengan dimensi keadilan yang berada dalam konteks relasi antara desa dengan supradesa (pusat dan daerah). Kemandirian desa berarti kapasitas dan inisiatif lokal yang kuat dalam gagasan, kehendak, dan kemauan desa yang berbasis pada kearifan lokal, komunalisme dan modal sosial. Sedangkan demokrasi adalah nilai dan sistem yang memberi bingkai tata pemerintahan desa.

Secara konseptual, demokrasi mengandung sejumlah prinsip dasar representasi, transparansi, akuntabilitas, responsifitas dan partisipasi, yang selanjutnya menjadi dasar pengelolaan kebijakan, perencanaan desa, pengelolaan keuangan desa dan pelayanan publik. Sedangkan kesejahteraan meliputi dua komponen besar, yakni penyediaan layanan dasar (pangan, papan, pendidikan dan kesehatan) dan pengembangan ekonomi desa yang berbasis pada potensi lokal. Desentralisasi memungkinkan alokasi sumberdaya pada desa, dan demokrasi memungkinkan pengelolaan sumberdaya desa berpihak pada rakyat desa.

Dalam perspektif sosiologis, desa-desa yang beragam di seluruh Indonesia sejak dulu merupakan basis penghidupan rakyat yang notabene mempunyai otonomi dalam mengelola tata kuasa dan tata kelola atas penduduk, pranata lokal dan sumber daya ekonomi.

Pertama, hal yang sama dengan upaya untuk menciptakan masyarakat adil dan makmur seperti yang diamanat dalam Pembukaan UUD NRI 1945, harus dimulai dengan paradigma pembangunan dari bawah (desa) karena sebagian besar penduduk
Indonesia dengan segala permasalahannya berada di desa. Pembangunan yang cenderung berorientasi pada pertumbuhan dan bias kota, menyebabkan arus urbanisasi penduduk desa ke kota dan menyebabkan kemiskinan dan keterbelakangan di desa.

Kedua, semua masyarakat lokal di Indonesia mempunyai kearifan lokal secara kuat yang mengandung "roh" kecukupan, keseimbangan dan keberlanjutan dalam mengelola sumberdaya alam dan penduduk. Oleh karena itu, UU Desa yang baru ini seyogianya juga mampu untuk memperbaiki kerusakan sosial, budaya, ekonomi dan politik desa.

Ketiga, pengaturan tentang pemerintahan desa dimaksudkan untuk merespon proses globalisasi, yang ditandai oleh proses liberalisasi informasi, ekonomi, teknologi, budaya, dll. Tantangan ini diperlukan institusi negara yang lebih kuat dalam menghadapi dengan pembagian tugas dan kewenangan secara rasional antara negara dengan daerah (desa). Prinsip dasar yang harus dipegang dalam pembagian tugas dan kewenangan adalah daerah dan desa dapat ditempatkan sebagai kompartemen-kompartemen fleksibel dalam negara dalam mewujudkan kesejahteraan masyarakat dan yang lebih mendasar adalah survival ability negara.

Keempat, penyerahan urusan/kewenangan dari kabupaten/kota kepada desa sebenarnya tidak dikenal dalam teori desentralisasi. Oleh karena itu, dengan terpisahnya pengaturan tentang Desa dari UU Pemerintahan Daerah, hal ini akan semakin mempertegas amanat dan makna Pasal 18 UUD 1945, sekaligus akan semakin memperjelas posisi atau kedudukan dan kewenangan desa atau memperjelas makna otonomi desa.

Dalam rangka pembangunan desa ke depan, ada baiknya bercermin pada konsep 
Saemaul Undong di Korea Selatan. Saemaul Undong mereplikasi cara membangkitkan ekonomi di desa. ${ }^{23}$ Dalam konsep ini, bantuan (dana) hanya sebagai pemicu saja, sedangkan yang lebih penting lagi adalah kampanye pembangunan mental dan revolusi mental. Intinya dikatakan bahwa pemerintah siap memberikan kail, sedangkan warga masyarakat desa mengupayakan tenaga penggeraknya.

Lebih lanjut, sebagaimana dikutip dalam Rohman Budijanto ${ }^{24}$ menyebutkan ada tiga strategi Saemual Undong: Pertama, pemerintah memicu kemampuan menolong diri sendiri dengan spirit ketelatenan, kemandirian dan kerja sama; Kedua, secara demokratis warga memilih proyek yang bias menguntungkan desa, bias dipraktekkan dan partisipasi sukarela. Ketiga, konsisten menerapkan prinsip mengutamakan dukungan ke desa yang kebanyakan untuk membangkitkan kemampuan menolong diri sendiri dan semangat kompetisi warga desa.

Dikaitkan dengan kondisi di Indonesia, kiranya Saemual Undong ini dapat disamakan dengan semangat gotong royong. Dengan demikian, sebenarnya telah terkandung semangat untuk membangun desa berpedoman kepada UU Desa, dan dasar filosofis negara (filosofische grondslag).

\section{PENUTUP}

Konsep "hukum sebagai sarana pembaharuan masyarakat" telah diwujudkan di Indonesia dalam bentuk terwujudnya UU Desa. Melalui UU Desa, hukum akan berperan positif dan responsif dalam upaya memberdayakan desa agar menjadi kuat, maju, mandiri, dan demokratis.

\footnotetext{
23 Harian Jawa Pos Senin 7 Juli 2014.

24 Ibid.
}

Paling tidak ada tiga hal yang segera dilakukan oleh pemerintah dalam menyikapi lahirnya UU Desa ini: Pertama, segera membentuk peraturan pemerintah tentang penye-lenggaraan pemerintahan desa yang intinya menjabarkan kewenangan desa dan hubu-ngannya dengan desa adat. Kedua, membentuk peraturan pemerintah yang mengatur mekanisme dari perencanaan sampai dengan pengawasan bantuan per desa yang bisa mencapai satu milyar rupiah itu. Ketiga, melaksanakan pengawasan yang komprehensif, untuk menghindari keraguan akan keefektifan UU Desa juga kekhawatiran terjadinya penyalahgunaan dana bantuan.

\section{BIBLIOGRAFI}

Achmad Ali. (2009). Menguak Teori Hukum (Legal Theory) dan Teori Peradilan (Judicialprudence). Jakarta: Prenada Media Grup.

Achmad Ruslan. (2013). Teori dan Panduan Praktik Pembentukan Peraturan Perundang-Undangan di Indonesia. Yogyakarta: Rangkang Education dan Republik Institut.

Ali Nawaz Soomro dan Amir Ali Chandio. (2013). Challenges to Good Government System of Pakistan, The Journal of African and Asia Local Government Studies, 2(4): 42-51, available at: http://www.enterforcalpoint.com.

Arbi Sanit. (2013). Politik Lokal di Bawah Pusaran Pemerintah Negara Kesatuan, Jurnal MIPI Edisi 28.

Bagir Manan. (1990). Hubungan antara Pusat dan Daerah Berdasarkan Asas Desentralisasi Menurut UUD 1945. Disertasi. Bandung: Pascasarjana Universitas Padjadjaran.

Didik Sukriono. (2011). Politik Hukum Pemerintahan Desa Perspektif Filosofis, Yuridis dan Sosiologis, Jurnal Kertha Wicaksana, 17(2): 176. 
Forum Desa. Available from: www.forumdesa.org/mudik/mudik/opim.php, [diakses pada 14 Januari 2015].

Hadin Muhjad dan Ninuk Nuswardani. (2012). Penelitian Hukum Indonesia Kontemporer. Yogyakarta: Genta Publishing.

Harian Jawa Pos, Edisi Senin, 7 Juli 2014.

I Dewa Gede Atmadja. (2008). Awig-Awig Desa Adat Bali: Suatu Analisis Hukum Tata Negara, Dalam Dinamika Perkembangan Hukum Tata Negara dan Hukum Lingkungan, Edisi Khusus dalam rangka Purnabakti Prof. Dr. Siti Sundari Rangkuti, S.K. Surabaya: Airlangga University Press.

I Nyoman Budiana. (2011). Memahami Otonomi desa Pakraman sebagai Kesatuan Masyarakat Hukum Adat di Bali (Kajian dari Perspektif Hirarki Peraturan Perundang-Undangan Indonesia), Jurnal Konstitusi PKK Universitas Pendidikan Nasional Denpasar, I(1) Juni 2011.

International Institute for Democracy and Electoral Assistance. (2011). A Practical Guide to Constitutional Building:
Decentralized Forms of Government, Stromsborg, Stockholm, Sweden, available from: http://www.idea.int.

Mochtar Kusumaatmadja. (1976). Hukum, Masyarakat dan Pembinaan Hukum Nasional, Suatu Uraian tentang Landasan Pikiran, Pola dan Mekanisme Pembaharuan Hukum di Indonesia, LPHK Fakultas Hukum Universitas Padjajaran. Bandung: Binatjipta.

R. Yando Zakaria dan Abih Tandeh. (2000). Masyarakat Desa di Bawah Rejim Orde Baru. Jakarta: Lembaga Studi dan Advokasi Masyarakat (ELSAM).

Sadu Wasistiono. (2006). Prospek Pengembangan Desa. Bandung: Lembaga Kajian Manajemen Pemerintahan Daerah, Fokus Media.

Syarif Hidayat. (2007). Too Much Too Soon, Local Elite's Perpective on and The Puzzle of Contemporary Indonesian Regional Autonomy Policy, Jakarta: Raja Grafindo Persada.

Wasisto Raharjo Jati. (2012). Inkonsistensi Paradigma Otonomi Daerah di Indonesia, Jurnal Konstitusi, 9(4) Desember 2012: 747. 